\title{
Description of three new species of Ninoe and Cenogenus (Polychaeta: Lumbrineridae) from the Mexican Pacific
}

\author{
PABLO HERNÁNDEZ-ALCÁNTARA, ALMA YAZMÍN PÉREZ-MENDOZA \\ and VIVIANNE SOLÍS-WEISS \\ Laboratorio de Ecología y Biodiversidad de Invertebrados Marinos, Instituto de Ciencias del Mar y Limnología, UNAM, \\ Apdo. Postal 70-305. México D.F. 04510, México. E-mail: solisw@mar.icmyl.unam.mx
}

\begin{abstract}
SUMMARY: In this study, 169 lumbrinerids of the genera Ninoe and Cenogenus from the sublittoral zone of the Gulf of California and Gulf of Tehuantepec were analysed. Previous records in these regions of the Mexican Pacific included five species of Ninoe ( $N$. chilensis, $N$. foliosa, $N$. gemmea, $N$. longibranchia and $N$. moorei) and two of Cenogenus (originally identified as Ninoe fusca and $N$. fuscoides). Ninoe jessicae and $N$. marthae are newly described. They are characterized by the presence of multidentate hooded hooks from chaetiger 1 and at least 7 branchial filaments in the best developed branchiae. N. marthae n. sp. differs not only from N. jessicae n. sp. but also from the other species of the Genus Ninoe, because only four teeth are present in maxilla II, while in all the other described species, 6-8 teeth are present there. The new species Cenogenus eliae is characterized by the presence of branchiae starting at chaetigers 32-51 and simple multidentate hooded hooks in all parapodia.
\end{abstract}

Keywords: Polychaete, new species, Lumbrineridae, Ninoe, Cenogenus, Mexican Pacific.

RESUMEN: Descripción de tres nUevas especies de Ninoe y Cenogennus (Polychaeta: Lumbrineridae) Del Pacífico MeXicano. - Se analizaron 169 lumbrinéridos de los géneros Ninoe y Cenogenus de la zona sublitoral del Golfo de California y Golfo de Tehuantepec. Los registros previos en esta zona del Pacífico Mexicano incluyen cinco especies de Ninoe ( $N$. chilensis, N. foliosa, N. gemmea, N. longibranchia y N. moorei) y dos de Cenogenus (originalmente identificadas como Ninoe fusca y $N$. fuscoides). Ninoe jessicae y $N$. marthae se describen por primera vez, y se caracterizan por presentar ganchos simples cubiertos multidentados a partir del quetígero 1 y al menos 7 filamentos cuando las branquias están mejor desarrolladas. N. marthae n. sp. difiere de $N$. jessicae n. sp. y de las otras especies del Género Ninoe por la presencia de cuatro dientes en la maxila II, ya que las especies descritas previamente tienen 6-8 dientes. La nueva especie Cenogenus eliae se caracteriza por la presencia de branquias a partir de los chaetigeros 32-51 y ganchos simples cubiertos multidentados en todos los parapodios.

Palabras clave: Poliquetos, nuevas especies, Lumbrineridae, Ninoe, Cenogenus, Pacífico Mexicano.

\section{INTRODUCTION}

The family Lumbrineridae is characterized by long, cylindrical, free-living burrowing polychaetes, with essentially identical chaetigers. Their morphological homogeneity and the reduced number of external characteristics make it difficult to separate the genera taxonomically (Oug, 2002).
In 1865 Kinberg established the Genus Ninoe to include the eunicemorphs with no prostomial appendices or tentacular cirri and with branchiae arising from the postchaetal lobes in anterior parapodia. Initially, he included three species from Chile and Brazil: N. chilensis, N. brasiliensis and N. oculata. Much later, Fauchald (1970) emended the genus to include all lumbrinerids with branchial 
processes whatever their origin, structure or position and no other characters considered. However, this amendment was rejected by Orensanz $(1973,1990)$ who considered that the lumbrinerids' "branchiae" are represented by two types of different structures that are not homologous. He differentiated the branchiae of Ninoe sensu stricto (which are unique in their position, shape and distribution), from the other "branchial" structures found in some lumbrinerids (constituted by branchial lobes such as those found in "Ninoe" dolichognatha Rioja, 1941). With this distinction, the species of the genus Ninoe sensu stricto can be clearly separated from the others, but the structure and origin of the branchial lobes still constitutes an unsolved problem, so that all species in which they are present have been grouped in genera such as Cenogenus or Paraninoe whose position is not yet universally accepted.

Initially, Chamberlin (1919) established the genus Cenogenus based on the presence of a conical nuchal process, four maxillae (III and IV with no teeth), limbate chaetae, simple multidentate hooded hooks and the presence in anterior parapodia of a cylindrical, slender, finger-like, and short, postchaetal process. In 1970, Fauchald considered this genus as a junior synonym of Lumbrineris sensu stricto; however, currently, Lumbrineris is considered a heterogenous taxon, which includes only lumbrinerids with no branchiae (Frame, 1992).

Levenstein (1977) named the genus Paraninoe to include all species with a nuchal organ and simple digitate branchiae, stating that the difference with Ninoe was in the number of branchial filaments and the shape of maxillae III and IV, which in the former lack teeth. However, Carrera-Parra (2001) in his revision of type material of Cenogenus descendens Chamberlin, 1919 and Ninoe fusca Moore, 1911 (type species of Paraninoe), concluded that the genus Cenogenus is valid and that Paraninoe is a junior synonym.

Traditionally, the identification of the genera and species in this family has been based on the external morphological characters. However, more recently, the trend in systematics of the lumbrinerids has been to include characters such as the maxillary apparatus, even if they are more difficult to observe. This is why the posterior region in most genera and species is not considered critical. However, when descriptions are carried out from incomplete material, caution should be the norm, since, as happens with Cenogenus eliae n. sp. the digitate branchiae,

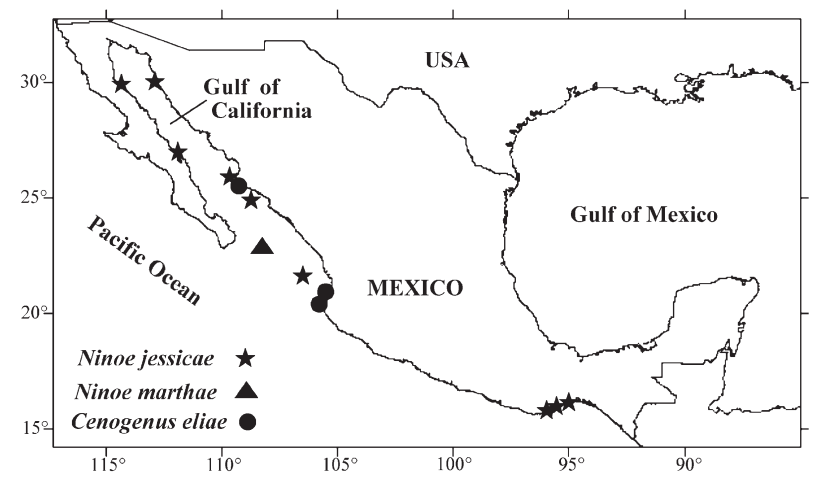

FIG. 1. - Distribution of the three new species described from the study area (Mexican Pacific).

one of the most important character, for species designation are not present before chaetigers 32-51.

In the Mexican Pacific Ocean (from sublittoral habitats to deep waters), reports of lumbrinerids with branchiae are sparse and only eight species have been recorded so far (Rioja, 1941; Fauchald, 1970, 1972; Salazar-Vallejo, 1981; Arias-González, 1984; LópezHernández, 1986; Sarti-Martínez and Solís-Weiss, 1987; Lezcano-Bustamante, 1989; Padilla-Galicia and Solís-Weiss, 1992; Hernández-Alcántara, 1992; Varela-Hernández, 1993; González-Ortiz, 1994): one corresponds to the genus Kuwaita, originally identified as Ninoe dolichognatha (Rioja, 1941), five to Ninoe (N. chilensis (Kinberg, 1865), N. foliosa Fauchald, 1972, N. gemmea Moore, 1911, N. longibranchia Fauchald, 1972 and N. moorei Rioja, 1941) and two to Cenogenus (originally identified as Ninoe fusca (Moore, 1911) and N. fuscoides (Fauchald, 1972)).

The aim of this study is to describe three new species of lumbrinerids, two from the genus Ninoe and one from Cenogenus, which were collected as part of different expeditions to the Gulf of California, Gulf of Tehuantepec and Mexican Pacific littoral regions. The area covered can be seen in Figure 1.

\section{MATERIALS AND METHODS}

The specimens were collected by personnel of the Instituto de Ciencias del Mar y Limnología (ICML), Universidad Nacional Autónoma de México (UNAM) on board R/V "El Puma" during the oceanographic expeditions "CORTES II", "MIMAR III", "MAZCAB II" and "SEDIMENTO I". The study area included the coasts of the Mexican Pacific (Fig. 1). Stations' position was determined by Global Positioning System (GPS). 
Samples were taken with a Smith-McIntyre grab $\left(0.1 \mathrm{~m}^{2}\right)$ or a US-NEL box corer $\left(0.25 \mathrm{~m}^{2}\right)$. The biological material was fixed in $10 \%$ formalin and preserved in $70 \%$ ethanol.

The holotypes and paratypes are deposited at the Polychaete Collection ICML-UNAM (CP-ICML). Additional paratypes are deposited at the Los Angeles County Natural History Museum (LACM), the Australian Museum (AM), The Natural History Museum, London (NHM).

The habitat data for each species are abbreviated as follows: $\mathrm{D}=$ depth in meters; $\mathrm{T}=$ temperature in ${ }^{\circ} \mathrm{C} ; \mathrm{S}=$ salinity in ppt; $\mathrm{DO}=$ dissolved oxygen in $\mathrm{ml} / \mathrm{l}$ (determined by the Winkler method (Strickland and Parsons, 1977)); OM = organic matter content in the sediments in \%C (determined by the Walkley-Black method (1934) modified by Jackson (1958)).

The diagnostic differences among the species described here were assessed by comparing selected morphological characters in the specimens coming from different localities (Population Aggregation Analysis) (Davis and Nixon, 1992). Fifteen variables were used to quantify the morphological differences among the populations of the species Ninoe jessicae, Ninoe marthae and Cenogenus eliae. The samples (n $=47$ ) of 11 populations, representative of the areas where the described species are distributed, were analysed. In Table 1, the characters evaluated are listed and correspond to the characters routinely used to diagnose lumbrinerid species (Uebelacker, 1984; Orensanz, 1990; Hilbig, 1995). The selected attributes can be coded as discrete alternative states; attributes 1-4 are binary, whereas 5-15 are multistate. Numbers designate individuals sampled from the same locality (A-K), and these individuals are taken to be members of the same interbreeding group.

\section{RESULTS}

For this study, 169 lumbrinerids with branchial processes were identified: two new species of the genus Ninoe and one new species of Cenogenus.

\section{Ninoe jessicae $\mathrm{n} . \mathrm{sp}$.}

(Fig. 2)

Material examined. 26 specimens: Holotype (CP-ICML: POH-54002), Expedition MIMAR III, Station $212,15^{\circ} 57.2^{\prime} \mathrm{N}, 95^{\circ} 20.1^{\prime} \mathrm{W}$ 01 June 1987, $70 \mathrm{~m}$; 5 paratypes (CP-ICML: POP-54-001), Expedition MIMAR III, sta. $212,15^{\circ} 57.2^{\prime} \mathrm{N}, 95^{\circ} 20.1^{\prime} \mathrm{W}, 01$ June 1987, 70 m; 5 paratypes (LACM-AHF POLY 2171), Expedition
MIMAR III, sta. 241, 1547.5’ N, 9555.4'W, 01 June 1987, 76 m; 5 paratypes (NHM: 2005.1517.1521), Expedition MIMAR III, sta. $212,15^{\circ} 57.2^{\prime} \mathrm{N}, 9^{\circ} 20.1^{\prime} \mathrm{W}, 01$ June $1987,70 \mathrm{~m} ; 5$ paratypes (AM: XXXXXX), Expedition MIMAR III, sta. $241,15^{\circ} 47.5^{\prime} \mathrm{N}$, 9555.4'W, 01 June 1987, $76 \mathrm{~m}$

Additional material examined: 68 specimens: Expedition MIMAR III, sta. $241,15^{\circ} 47.5^{\prime} \mathrm{N}, 95^{\circ} 55.4^{\prime} \mathrm{W}, 01$ June $1987,76 \mathrm{~m}$, (11 specimens); Expedition MIMAR III, sta. 230, 1552.4' N, 9540.0' W, 01 June 1987, 94 m (2 specimens); Expedition MIMAR III, Station $223,15^{\circ} 56.0^{\prime} \mathrm{N}, 95^{\circ} 30.3^{\prime} \mathrm{W}, 01$ June $1987,78 \mathrm{~m}$ (3 specimens); Expedition MIMAR III, sta. 222, 1553.4' N, 95³0.2' W, 01 June 1987, 94 m (3 specimens); Expedition MIMAR III, sta. 212, $15^{\circ} 57.2^{\prime} \mathrm{N}, 95^{\circ} 20.1^{\prime} \mathrm{W}, 01$ June $1987,70 \mathrm{~m}$ (21 specimens); Expedition MIMAR III, sta. 202, $16^{\circ} 06.5^{\prime} \mathrm{N}, 95^{\circ} 10.5^{\prime} \mathrm{W}, 31$ May 1987, $20 \mathrm{~m}$ (4 specimens); Expedition MIMAR III, sta. 187, $15^{\circ} 58.1^{\prime} \mathrm{N}, 94^{\circ} 59.9^{\prime} \mathrm{W}, 31$ May 1987, $97 \mathrm{~m}$ (6 specimens); Expedition CORTES II, sta. 5, 24⒌ 54.6' N, 108²5.3' W, 10 March 1985, $120 \mathrm{~m}$ (1 specimen); Expedition CORTES II, sta. 33, $29^{\circ} 55.4^{\prime} \mathrm{N}, 114^{\circ} 19.3^{\prime} \mathrm{W}, 15$ March $1985,82 \mathrm{~m}$ (7 specimens); Expedition CORTES II, sta. 44, 3002.4' N, $112^{\circ} 55.4^{\prime} \mathrm{W}, 17$ March 1985, $104 \mathrm{~m}$ (3 specimens); Expedition CORTES II, sta. 49B, 26⒌ 59. N, 111 ${ }^{\circ} 53.5^{\prime} \mathrm{W}, 19$ March 1985, $69 \mathrm{~m}$ (1 specimen); Expedition CORTES II, sta. 51, 2542.1' N, 109 30.6' W, 21 March 1985, $46 \mathrm{~m}$ (1 specimen); Expedition CORTES II, sta. 62D, $21^{\circ} 38.4^{\prime} \mathrm{N}, 106^{\circ} 31.9^{\prime} \mathrm{W}, 22$ March $1985,132 \mathrm{~m}$ (5 specimens).

Description. The description is based on the holotype unless specified otherwise. Holotype complete with 139 chaetigers: $28.9 \mathrm{~mm}$ long and $1.3 \mathrm{~mm}$ wide. Some fixed paratypes with reddish coloration along the body, covering 3 to 8 chaetigers. Prostomium conical, as long as wide, with blunt end. Peristomium formed by a pair of rings (Fig. 2a). Nuchal organs like small furrows. No eyes. Maxillary apparatus: MI unidentate curved and forceps-like; MII with six teeth; MIII and MIV unidentate, with irregularly serrated cutting edges (Fig. $2 b$ ); mandibles slender, with anterior ends flared.

Branchiae present from first or second chaetiger (Fig. 2c) as far as chaetigers 19-33; first branchial pairs with only one filament, in following pairs the number increases, to a maximum of 12 filaments. Dorsal filament is longer and thicker than the others (Figs. d, e).

Body sturdy, cylindrical; chaetigers short with similar thickness along body. In the postbranchial region, chaetigers short with short digitiform dorsal postchaetal lobe, shorter than hooks.

Chaetae limbate, distally pointed (Fig. 2g), 1-5 per chaetiger. In postbranchial chaetigers, limbate chaetae diminish in number, only 1 or 2 per parapodium in the posterior region; with 1-2 yellowish brown aciculae. Chaetae also include 1-4 multidentate hooded hooks present from first chaetiger; with one tooth and four or five apical denticles (Fig. 2h).

Pygidium with two anal cirri.

Etymology. The species is named after Perla Jessica Pérez Mendoza, sister of one of us (AYPM). 


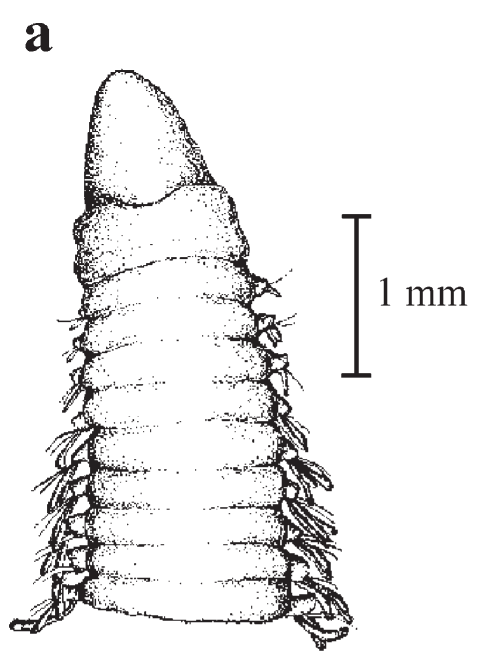

b
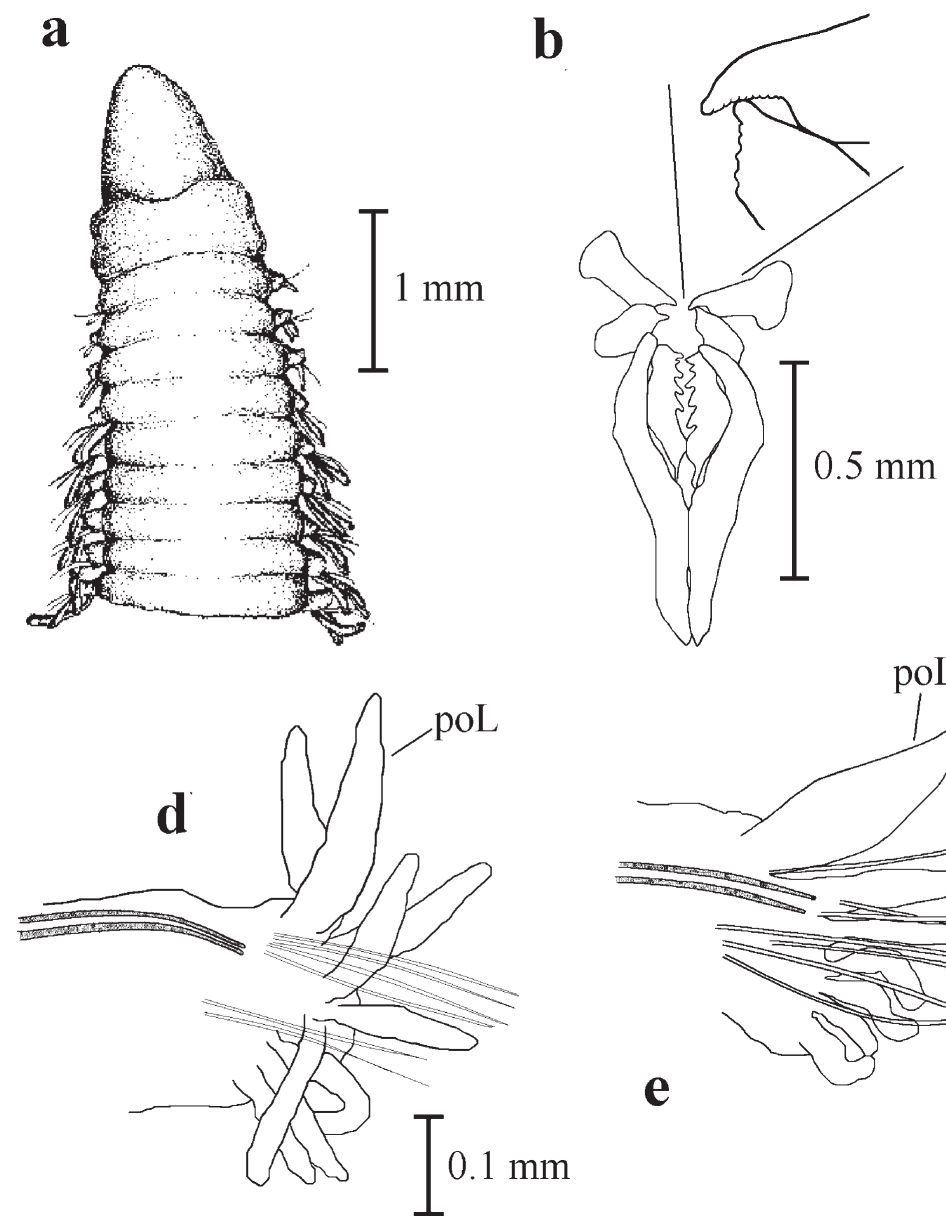

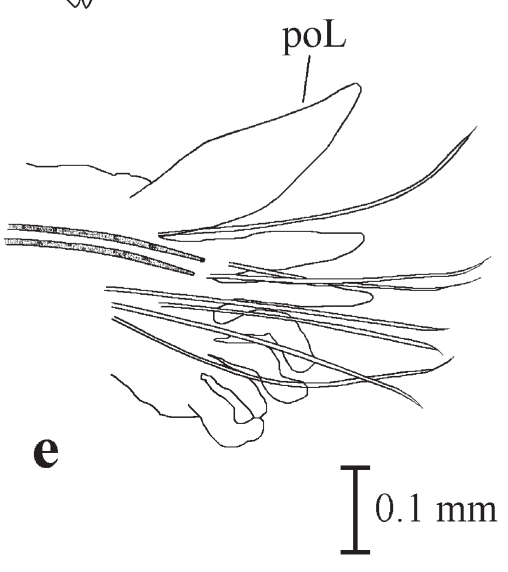

c

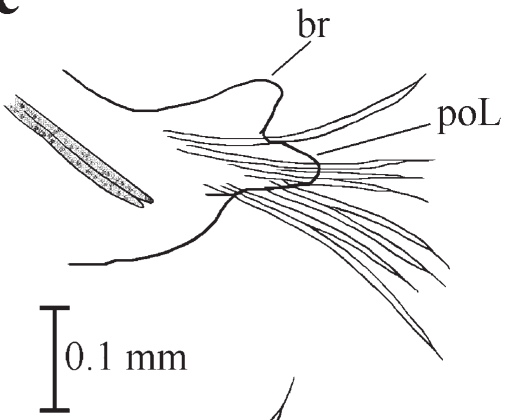

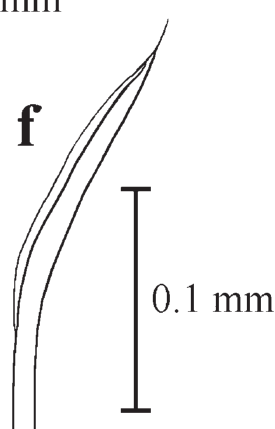

FIG. 2. - Ninoe jessicae n. sp.: a, anterior end, dorsal view; b, maxillae; c, parapodium from chaetiger 1; d, parapodium from chaetiger 18; $\mathrm{e}$, parapodium from midbody region; $\mathrm{f}$, limbate chaetae; $\mathrm{g}$, hooded hook ( $\mathrm{poL}=$ postchaetal lobe; $\mathrm{br}=\mathrm{branchiae}$ ).

Remarks. The branchial distribution and the maximum number of branchial filaments of the new species $N$. jessicae, only resemble $N$. foliosa Fauchald, 1972 (branchiae from chaetiger 2 to 36, with up to 12-13 filaments), recorded for Sal si Puedes Basin in the Gulf of California and in San Cristobal Bay (Pacific side of Baja California), and $N$. chilensis Kinberg, 1865 (branchiae from chaetigers 1 or 2 to $28-41$, with 12 filaments), originally recorded from shallow waters of the central part of Chile, but widely distributed in the warmtemperate waters of the south American Pacific coasts. According to Orensanz (1990), who examined the type material of $N$. chilensis and an extensive topotypic collection of the same species from Valparaiso Bay (Chile), N. foliosa is so similar morphologically to $N$. chilensis that it could well be a junior synonym of the latter. Although these two species are very similar to $N$. jessicae n. sp., in the distribution and development of their branchiae and their maxillary apparatus, they can be clearly differentiated from the latter by the simple multidentate hooded hooks, which are present after chaetiger 25 in $N$. foliosa and N. chilensis. So, $N$. jessicae $\mathrm{n}$. sp. belongs to the set of species in the genus Ninoe which have not lost their anterior hooks in the course of lumbrinerid evolution (Orensanz, 1990), which is why the simple multidentate hooded hooks are present from chaetiger 1, as in N. palmata Moore, 1903, N. gemmea Moore, 1911 and N. longibranchia Fauchald, 1972. However, there are also other differences between these species and $N$. jessicae n. sp., especially a lower number of branchial filaments in the former group of species (6 at most).

Habitat. 20-120 $\mathrm{m}$ depth, in silty sands, muddy sands and muds, $\mathrm{T}=12.9-30^{\circ} \mathrm{C}, \mathrm{S}=34.98-35.33$, $\mathrm{DO}=0.20-2.40 \mathrm{ml} / \mathrm{l}, \mathrm{OM}=0.28-7.2 \%$.

Distribution. Gulf of California and Gulf of Tehuantepec, Mexican Pacific (Fig. 1). 

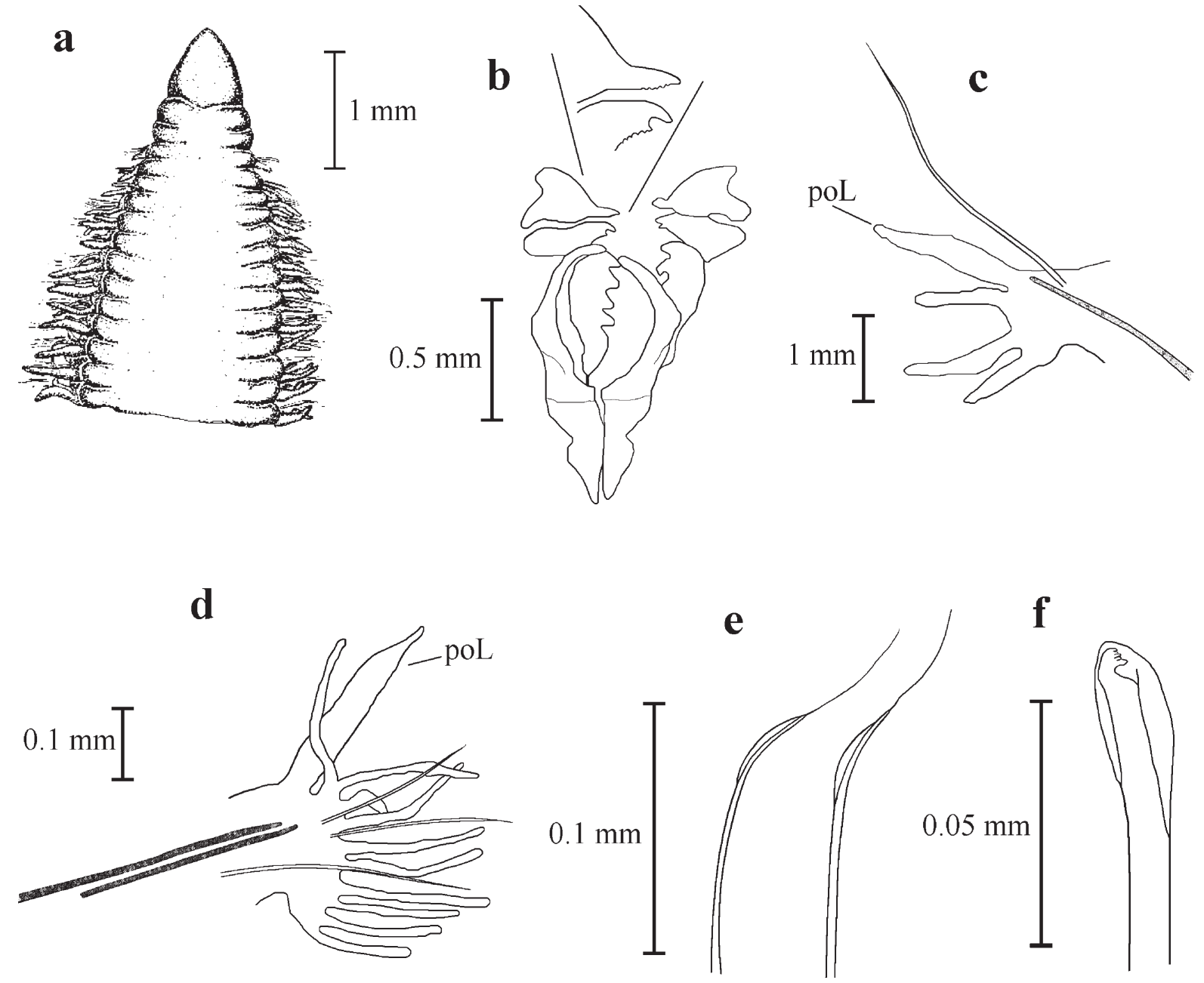

FIG. 3. - Ninoe marthae n. sp.: a, anterior end, dorsal view; b, maxillae; c, parapodium from chaetiger 3; d, parapodium from chaetiger 19; $\mathrm{e}$, limbate chaetae; $\mathrm{f}$, hooded hook ( $\mathrm{poL}=$ postchaetal lobe).

Ninoe marthae n. sp.

(Fig. 3)

Material examined. 2 specimens: Holotype (CP-ICML: POH-54001), Expedition MAZCAB II, sta. 3, $22^{\circ} 58.1^{\prime} \mathrm{N}, 108^{\circ} 15.5^{\prime} \mathrm{W}, 16$ May 1998, $2950 \mathrm{~m} ; 1$ paratypes (CP-ICML: POP-54-002), Expedition MAZCAB II, sta. 3, $22^{\circ} 58.1^{\prime} \mathrm{N}, 108^{\circ} 15.5^{\prime} \mathrm{W}, 16$ May $1998,2950 \mathrm{~m}$.

Description. Holotype incomplete with 55 chaetigers, $15.8 \mathrm{~mm}$ long and $0.7 \mathrm{~mm}$ wide. Prostomium conical, as long as wide, nuchal organs formed by two small furrows in the occipital region, with a protuberance in the central portion of the prostomium. No eyes. Prostomium and peristomium dorsally smooth (Fig. 3a). Peristomium formed by two rings dorsally and laterally visible, fused in the ventral part to form a rim around the mouth. Maxilla and maxillary carriers long, scarcely pigmented. MI forceps-like, unidentate and curved; MII with four teeth; MIII bidentate and MIV unidentate (3b), with finely serrated cutting edge; mandibles fused along proximal half.

Parapodia rounded. Prechaetal lobes short and rounded, postchaetal lobes longer and conical. Branchiae present from chaetigers 1 or 2 to 17 (Fig. $3 c$ ); with up to 7-9 filaments, dorsal filament larger and thicker (Fig. 3d); a few first and last branchial pairs with two to three filaments.

Capillary chaetae limbate, with one of the wings wider in one margin and long filiform tip; length of the wide wing located at the distal part of the chaeta approximately one fifth of total chaetal length (Fig. 3e). Multidentate simple hooded hooks from chaetiger 1, present in all following chaetigers of the incomplete organism; with four to five distal denticles (Fig. 3f). First hooks with distal part poorly developed, posterior hooks thicker, with a larger basal tooth than those located in anterior chaetigers. Each anterior parapodium with 4-5 limbate chaetae 
and 1-2 simple hooks, in posterior chaetigers, 1-2 limbate chaetae and 3-4 simple hooks. With one or two dark amber-coloured aciculae (darker than the chaetae, but not black).

Etymology. The species is named after Martha del Rocio Pérez Mendoza, sister of one of us (AYPM).

Remarks. As in N. jessicae n. sp. described above, in $N$. marthae n. sp. simple multidentate hooded hooks are present in anterior chaetigers with a relatively large number of branchial filaments (up to 7-9). This is the main difference from other similar species which have numerous branchial filaments such as $N$. foliosa Fauchald, 1972 and N. chilensis Kinberg, 1865, where the simple hooks are found after chaetiger 25 . In addition, N. marthae n. sp. differs not only from N.jessicae $\mathrm{n}$. sp. but also from the other species of the Genus Ninoe, because only four teeth are present in maxilla II, while in all the other described species, 6-8 teeth are present there.

Habitat. Continental shelf $(85 \mathrm{~m})$ and deep-sea (600-2700 m), in muddy sands and muds.

Distribution. Southern Gulf of California, Mexican Pacific (Fig. 1).

\section{Cenogenus eliae $\mathrm{n}$. $\mathrm{sp}$.}

(Fig. 4)

Material examined. 7 specimens: Holotype (CP-ICML: POH-54003), Expedition CORTES II, sta. 60, 20 $0^{\circ} 51.6^{\prime} \mathrm{N}, 105^{\circ} 33.5^{\prime} \mathrm{W}, 23$ March 1985, 76 m; 6 paratypes, Expedition CORTES II, sta. 60 $20^{\circ} 51.6^{\prime} \mathrm{N}, 105^{\circ} 33.5^{\prime} \mathrm{W}, 23$ March 1985, $76 \mathrm{~m}: 2$ specimens (LACM-AHF POLY 2172); 4 specimens (CP-ICML: POP-54-003).

Additional material examined. 66 specimens: Expedition CORTES II, sta. $61,20^{\circ} 53.9^{\prime} \mathrm{N}, 105^{\circ} 27.5^{\prime} \mathrm{W}, 23$ March 1985, $50 \mathrm{~m}$ (7 specimens); Expedition CORTES II, sta. 60, 20 $51.6^{\prime} \mathrm{N}, 105^{\circ} 33.5^{\prime} \mathrm{W}, 23$ March 1985, 76 m (58 specimens); Expedition CORTES II, sta. 52, $25^{\circ} 39.9^{\prime} \mathrm{N}, 109^{\circ} 28.6^{\prime} \mathrm{W}, 20$ March 1985, $28.6 \mathrm{~m}$ (1 specimen).

Description: Holotype incomplete with 71 chaetigers, $9.5 \mathrm{~mm}$ long and $0.45 \mathrm{~mm}$ wide. Prostomium conical, as long as wide, no eyes; the small antenna in the nuchal fold often difficult to see (Fig. 4a). Nuchal organs formed by two small furrows. Peristomium with two well developed rings, dorsally and laterally divided between them, but fused ventrally, forming a rim-like structure around the mouth. Maxillary structure: MI unidentate and curved, forceps-like; MII with three teeth; MIII and
MIV triangular edentate plates with smooth cutting edge (Fig. 4b); mandibles partially fused.

Anterior parapodia with prechaetal lobes short and rounded, postchaetal lobes approximately double the length of prechaetal ones (Figs. 4c, d). Branchiae start at chaetigers 32-51, first as small protuberances in medial-dorsal portion of postchaetal lobe, quickly increasing in size together with the postchaetal lobe; towards posterior region of body, length of branchiae can be almost equal to width of body, always depending on size of the postchaetal lobe; postchaetal lobes also increase in size towards the end of body, becoming similar in length to the branchiae so that the two structures together appear like two branchial filaments (Figs. 4e, f).

Limbate chaetae with wings long and wide (Fig. $4 \mathrm{~g}$ ); simple multidentate hooded hooks, with main fang clearly larger than the numerous distal denticles (Fig. 4h). Each of first 18 chaetigers with 3-4 limbate chaetae and one or two simple hooks; in following 10-20 chaetigers, hooks with single limbate chaeta, and in posterior chaetigers only simple hooks. Aciculae and bases of the chaetae dark amber.

Etymology. The species is named after Elia Mendoza Mendoza, mother of one of us (AYPM).

Remarks. Cenogenus differs from Ninoe, the other genus that includes lumbrinerids with branchiae, in the number of the branchiae and the structure of maxillae III and IV. In Ninoe, a variable number of anterior parapodia with postchaetal branchial lobes are present and maxillae III and IV are dentate along their cutting edge, while in Cenogenus the digitate branchiae are associated with the postchaetal lobe, and maxillae III and IV have a smooth cutting edge (CarreraParra, 2001). In Cenogenus eliae n. sp., the structure and distribution of the maxillae and the branchiae, we believe both being valid diagnostic characters, indicate it belongs to this genus; Carrera-Parra (2001) in its redescription and emendation of Cenogenus, states that the branchiae are present in the parapodia of the anterior region of the body. From the ten species presently included in the genus (Carrera-Parra, 2001), in $C$. abyssalis (Imajima and Higuchi, 1975) from Sagami Bay, Japan, C. nagae (Levenstein, 1977) from Nha Trang, South Viet Nam, and C. simpla 

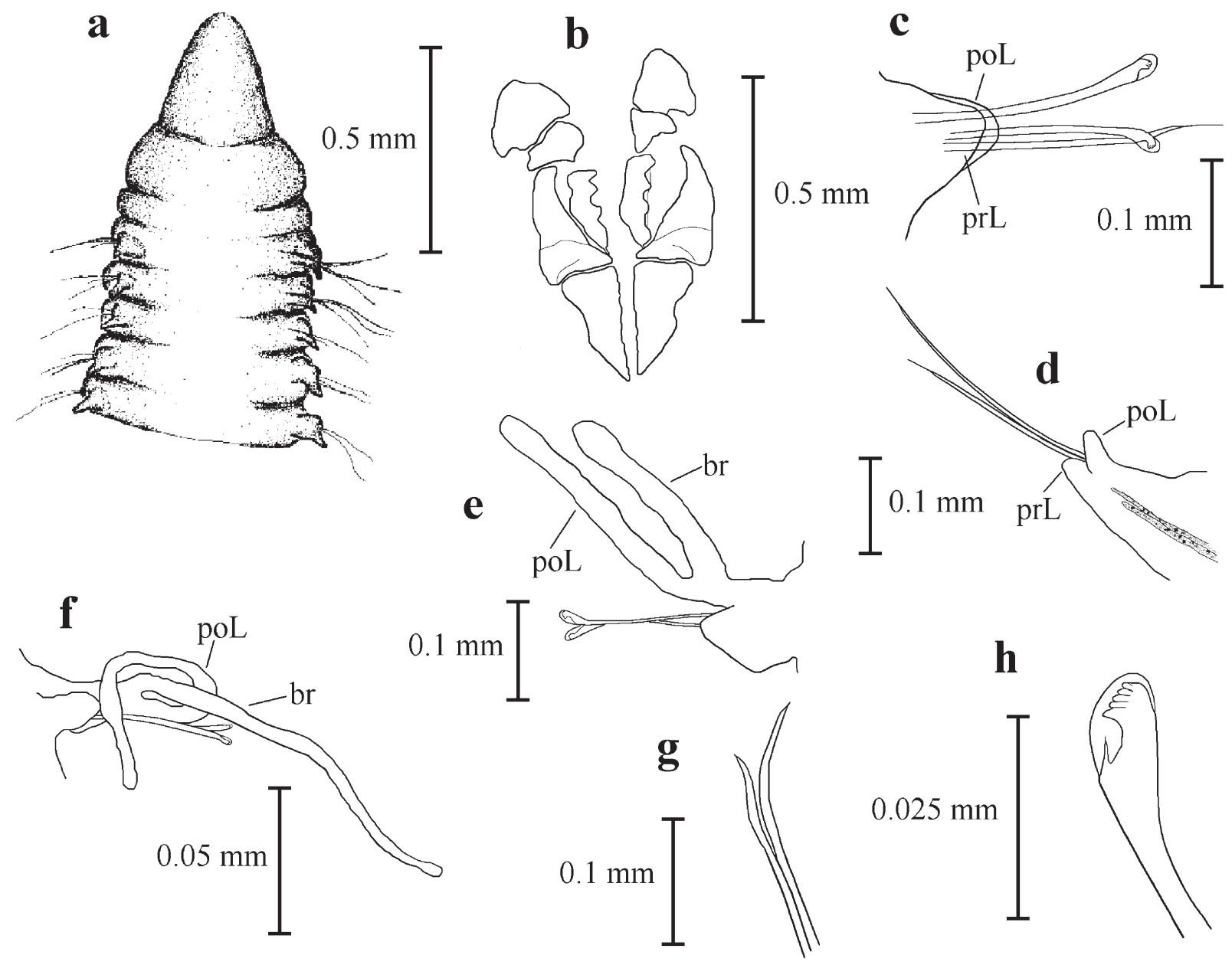

FIG. 4. - Cenogenus eliae n. sp.: a, anterior end, dorsal view; b, maxillae; c, parapodium from chaetiger 1; d, parapodium from chaetiger 10; e, parapodium from chaetiger 48; f, parapodium from posterior region, anterior view; g, simple chaetae; h, hooded hook ( $p r L=$ prechaetal lobe; $\mathrm{poL}=$ postchaetal lobe; $\mathrm{br}=$ branchiae) .

(Moore, 1905) from Alaska, the branchiae start between chaetigers 14 and 23 ; in the other species, the branchiae are present from chaetigers 1 or 2 . In this feature, C. eliae clearly differs from all the other species of the genus since the branchiae start at or after chaetiger 51 .

The specimens included in the "additional material examined" are anterior fragments with less than 40 segments, which makes it impossible to examine the branchial lobes. However, other diagnostic characters such as the structure of MIII and MIV enabled us to identify these specimens as C. eliae n. sp.

Habitat. 28-76 $\mathrm{m}$ depth, in fine sands and silty sands, $\mathrm{T}=15.3-16.8, \mathrm{~S}=34.92-35.19, \mathrm{DO}=0.76$ $5.40, \mathrm{OM}=3.6-5.5$.

Distribution. Eastern coasts from central and southern regions of the Gulf of California (Fig. 1).

\section{Delimiting species by the method of Population Aggregation Analysis (PAA)}

The methodological aspects necessary to delimit species are not well developed, among other reasons, due to problems related to the species concept itself. The different concepts of species include a host of arguments but De Queiroz (1998) indicated that all species concepts agree fundamentally on what species are (distinct evolutionary entities), but differ in criteria for their recognition. In this sense, Davis and Nixon (1992) suggested the Population Aggregation Analysis (PAA) as a method to delimit species, based on two fundamental principles: a) all individuals from a local population are considered to belong to the same species and, b) the individuals that share identical attributes, but come from different populations constitute evidence for co-specificity. Conceptually, 
TABLE 1. - Population Aggregation Analysis (PAA).

\begin{tabular}{|c|c|c|c|c|c|c|c|c|c|c|c|c|c|c|c|}
\hline \multirow{2}{*}{$\begin{array}{l}\text { Sample } \\
\text { individual }\end{array}$} & \multicolumn{15}{|c|}{ Biological attributes } \\
\hline & 1 & 2 & 3 & 4 & 5 & 6 & 7 & 8 & 9 & 10 & 11 & 12 & 13 & 14 & 15 \\
\hline \multicolumn{16}{|c|}{ A (MIMAR III sta. 187) } \\
\hline 1 & 1 & 1 & 1 & 0 & 1 & 6 & 1 & 1 & 2 & 1 & 12 & 30 & 1 & $2-4$ & $1-4$ \\
\hline 2 & 1 & 1 & 1 & 0 & 1 & 6 & 1 & 1 & 2 & 1 & 11 & 32 & 1 & $2-3$ & $1-4$ \\
\hline 3 & 1 & 1 & 1 & 0 & 1 & 6 & 1 & 1 & 2 & 1 & 12 & 29 & 1 & $2-4$ & $2-5$ \\
\hline 4 & 1 & 1 & 1 & 0 & 1 & 6 & 1 & 1 & 2 & 1 & 11 & 31 & 1 & $2-3$ & $2-4$ \\
\hline 5 & 1 & 1 & 1 & 0 & 1 & 6 & 1 & 1 & 2 & 1 & 12 & 33 & 1 & $2-4$ & $2-4$ \\
\hline Population profile & 1 & 1 & 1 & $\mathbf{0}$ & 1 & 6 & 1 & 1 & 2 & 1 & +- & +- & 1 & +- & +- \\
\hline \multicolumn{16}{|c|}{ B (MIMAR III sta. 202) } \\
\hline 1 & 1 & 1 & 1 & 0 & 1 & 6 & 1 & 1 & 2 & 2 & 8 & 22 & 1 & $2-4$ & $2-4$ \\
\hline 2 & 1 & 1 & 1 & 0 & 1 & 6 & 1 & 1 & 2 & 2 & 8 & 23 & 1 & $2-4$ & $1-5$ \\
\hline 3 & 1 & 1 & 1 & 0 & 1 & 6 & 1 & 1 & 2 & 2 & 10 & 20 & 1 & $2-4$ & $2-4$ \\
\hline 4 & 1 & 1 & 1 & 0 & 1 & 6 & 1 & 1 & 2 & 2 & 10 & 22 & 1 & $2-4$ & $2-4$ \\
\hline 5 & 1 & 1 & 1 & 0 & 1 & 6 & 1 & 1 & 2 & 2 & 9 & 20 & 1 & $2-4$ & $2-4$ \\
\hline Population profile & 1 & 1 & 1 & $\mathbf{0}$ & 1 & 6 & 1 & 1 & 2 & 2 & +- & +- & 1 & $2-4$ & +- \\
\hline \multicolumn{16}{|c|}{ C (MIMAR III sta. 222) } \\
\hline 1 & 1 & 1 & 1 & 0 & 1 & 6 & 1 & 1 & $1-2$ & 1 & 12 & 30 & 1 & $2-4$ & $2-4$ \\
\hline 2 & 1 & 1 & 1 & 0 & 1 & 6 & 1 & 1 & 2 & 1 & 10 & 29 & 1 & $2-4$ & $2-4$ \\
\hline 3 & 1 & 1 & 1 & 0 & 1 & 6 & 1 & 1 & 2 & 1 & 12 & 29 & 1 & $2-4$ & $2-4$ \\
\hline Population profile & 1 & 1 & 1 & $\mathbf{0}$ & 1 & 6 & 1 & 1 & +- & 1 & +- & +- & 1 & $2-4$ & $2-4$ \\
\hline \multicolumn{16}{|c|}{ D (MIMAR III sta. 230) } \\
\hline 1 & 1 & 1 & 1 & 0 & 1 & 6 & 1 & 1 & $1-2$ & 2 & 12 & 30 & 1 & $2-4$ & $1-4$ \\
\hline 2 & 1 & 1 & 1 & 0 & 1 & 6 & 1 & 1 & $1-2$ & 1 & 11 & 28 & 1 & $2-4$ & $1-4$ \\
\hline Population profile & 1 & 1 & 1 & $\mathbf{0}$ & 1 & 6 & 1 & 1 & $1-2$ & +- & +- & +- & 1 & $2-4$ & $1-4$ \\
\hline \multicolumn{16}{|c|}{ E (CORTES II sta. 33) } \\
\hline 1 & 1 & 1 & 1 & 0 & 1 & 6 & 1 & 1 & 2 & 2 & 8 & 23 & 1 & $2-4$ & $2-4$ \\
\hline 2 & 1 & 1 & 1 & 0 & 1 & 6 & 1 & 1 & 2 & 2 & 8 & 21 & 1 & $2-3$ & $2-4$ \\
\hline 3 & 1 & 1 & 1 & 0 & 1 & 6 & 1 & 1 & 2 & 1 & 7 & 25 & 1 & $2-4$ & $1-5$ \\
\hline 4 & 1 & 1 & 1 & 0 & 1 & 6 & 1 & 1 & 2 & 1 & 7 & 21 & 1 & $2-4$ & $1-4$ \\
\hline 5 & 1 & 1 & 1 & 0 & 1 & 6 & 1 & 1 & 2 & 2 & 7 & 21 & 1 & $2-4$ & $2-4$ \\
\hline Population profile & 1 & 1 & 1 & $\mathbf{0}$ & 1 & 6 & 1 & 1 & 2 & +- & +- & +- & 1 & +- & +- \\
\hline \multicolumn{16}{|c|}{ F (CORTES II sta. 44) } \\
\hline 1 & 1 & 1 & 1 & 0 & 1 & 6 & 1 & 1 & $1-2$ & 2 & 10 & 26 & 1 & $2-5$ & $2-4$ \\
\hline 2 & 1 & 1 & 1 & 0 & 1 & 6 & 1 & 1 & $1-2$ & 2 & 8 & 24 & 1 & $1-4$ & $1-5$ \\
\hline 3 & 1 & 1 & 1 & 0 & 1 & 6 & 1 & 1 & 2 & 2 & 10 & 27 & 1 & $4-5$ & $2-5$ \\
\hline 4 & 1 & 1 & 1 & 0 & 1 & 6 & 1 & 1 & 2 & 2 & 9 & 27 & 1 & $2-5$ & $2-5$ \\
\hline 5 & 1 & 1 & 1 & 0 & 1 & 6 & 1 & 1 & 2 & 2 & 8 & 24 & 1 & $1-4$ & $2-5$ \\
\hline Population profile & 1 & 1 & 1 & $\mathbf{0}$ & 1 & 6 & 1 & 1 & +- & 2 & +- & +- & 1 & +- & +- \\
\hline
\end{tabular}

G (CORTES II sta. 62D)

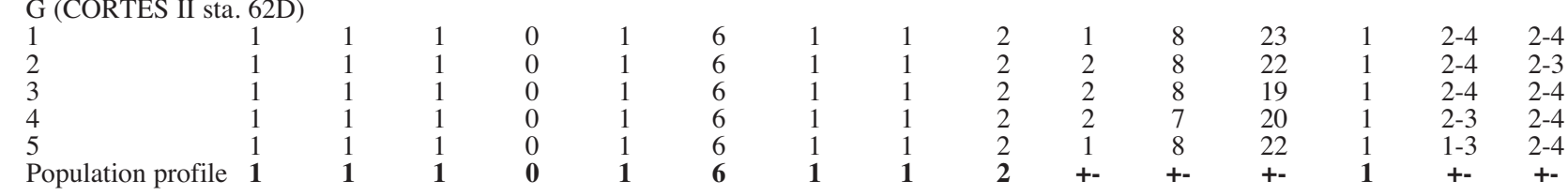

\begin{tabular}{|c|c|c|c|c|c|c|c|c|c|c|c|c|c|c|}
\hline H (MIMAR III sta. & & & & & & & & & & & & & & \\
\hline 1 & 1 & 1 & 0 & 1 & 6 & 1 & 1 & 2 & 1 & 12 & 30 & 1 & $1-4$ & $2-4$ \\
\hline 2 & 1 & 1 & 0 & 1 & 6 & 1 & 1 & $1-2$ & 2 & 10 & 29 & 1 & $2-4$ & $1-4$ \\
\hline 3 & 1 & 1 & 0 & 1 & 6 & 1 & 1 & $1-2$ & 2 & 12 & 27 & 1 & $2-4$ & $1-5$ \\
\hline 4 & 1 & 1 & 0 & 1 & 6 & 1 & 1 & 2 & 2 & 11 & 27 & 1 & $2-4$ & $2-4$ \\
\hline 5 & 1 & 1 & 0 & 1 & 6 & 1 & 1 & 2 & 2 & 12 & 28 & 1 & $2-4$ & $2-4$ \\
\hline Population profile & 1 & 1 & $\mathbf{0}$ & 1 & 6 & 1 & 1 & +- & +- & +- & +- & 1 & +- & \\
\hline
\end{tabular}

I (MIMAR III sta. 241)

\begin{tabular}{|c|c|c|c|c|c|c|c|c|c|c|c|c|c|c|c|}
\hline 1 & 1 & 1 & 1 & 0 & 1 & 6 & 1 & 1 & 2 & 1 & 11 & 27 & 1 & $2-4$ & $1-5$ \\
\hline 2 & 1 & 1 & 1 & 0 & 1 & 6 & 1 & 1 & 2 & 1 & 12 & 28 & 1 & $2-4$ & $1-5$ \\
\hline 3 & 1 & 1 & 1 & 0 & 1 & 6 & 1 & 1 & 2 & 1 & 11 & 28 & 1 & $2-4$ & $1-4$ \\
\hline 4 & 1 & 1 & 1 & 0 & 1 & 6 & 1 & 1 & 2 & 1 & 12 & 29 & 1 & $2-5$ & $2-4$ \\
\hline 5 & 1 & 1 & 1 & 0 & 1 & 6 & 1 & 1 & $1-2$ & 2 & 11 & 26 & 1 & $2-4$ & $1-5$ \\
\hline Population profile & 1 & 1 & 1 & $\mathbf{0}$ & 1 & 6 & 1 & 1 & +- & +- & +- & +- & 1 & +- & + \\
\hline
\end{tabular}

\begin{tabular}{|c|c|c|c|c|c|c|c|c|c|c|c|c|c|c|}
\hline J (MAZCAB II sta. & & & & & & & & & & & & & & \\
\hline 1 & 1 & 1 & 1 & 1 & 4 & 2 & 1 & $1-2$ & 2 & 9 & 25 & 1 & $2-4$ & $1-5$ \\
\hline 2 & 1 & 1 & 1 & 1 & 4 & 2 & 1 & $1-2$ & 1 & 7 & 17 & 1 & $1-3$ & $2-4$ \\
\hline Population profile & 1 & 1 & 1 & 1 & 4 & 2 & 1 & $1-2$ & +- & +- & +- & 1 & +- & +- \\
\hline
\end{tabular}


TABle 1 (Cont.). - Population Aggregation Analysis (PAA).

\begin{tabular}{|c|c|c|c|c|c|c|c|c|c|c|c|c|c|c|c|}
\hline \multirow{2}{*}{$\begin{array}{l}\text { Sample } \\
\text { individual }\end{array}$} & \multirow[b]{2}{*}{1} & \multirow[b]{2}{*}{2} & \multirow[b]{2}{*}{3} & \multirow[b]{2}{*}{4} & \multirow[b]{2}{*}{5} & \multirow[b]{2}{*}{6} & \multicolumn{4}{|c|}{ Biological attributes } & \multirow[b]{2}{*}{11} & \multirow[b]{2}{*}{12} & \multirow[b]{2}{*}{13} & \multirow[b]{2}{*}{14} & \multirow[b]{2}{*}{15} \\
\hline & & & & & & & 7 & 8 & 9 & 10 & & & & & \\
\hline \multicolumn{16}{|c|}{ K (CORTES II, sta. 60) } \\
\hline 1 & 0 & 0 & 0 & 1 & 1 & 3 & 0 & 0 & 2 & 44 & 1 & $?$ & 1 & $1-3$ & $1-4$ \\
\hline 2 & 0 & 0 & 0 & 1 & 1 & 3 & 0 & 0 & 2 & 49 & 1 & $?$ & 1 & $1-3$ & $1-4$ \\
\hline 3 & 0 & 0 & 0 & 1 & 1 & 3 & 0 & 0 & 2 & 34 & 1 & $?$ & 1 & $1-3$ & $1-4$ \\
\hline 4 & 0 & 0 & 0 & 1 & 1 & 3 & 0 & 0 & 2 & 51 & 1 & $?$ & 1 & $1-2$ & $1-4$ \\
\hline 5 & 0 & 0 & 0 & 1 & 1 & 3 & 0 & 0 & 2 & 40 & 1 & $?$ & 1 & $1-3$ & $1-3$ \\
\hline Population profile & $\mathbf{0}$ & $\mathbf{0}$ & $\mathbf{0}$ & 1 & 1 & 3 & $\mathbf{0}$ & $\mathbf{0}$ & 2 & +- & 1 & $?$ & 1 & +- & +- \\
\hline
\end{tabular}

1) Branchiae before chaetiger $32(0=$ no; $1=$ yes $) ; 2)$ Maxilla III with a finely serrated edge $(0=$ no; $1=$ yes $)$; 3$)$ Maxilla IV with a finely serrated edge $(0=$ no; 1 = yes $) ; 4)$ Aciculae $(0=$ yellowish; $1=$ darker $) ; 5)$ Maxilla I, number of teeth; 6$)$ Maxilla II, number of teeth; 7$)$ Maxilla III, number of teeth; 8) Maxilla IV, number of teeth; 9) Number of aciculae per parapodium; 10) Number of chaetiger at which branchiae start; 11) Maximum number of branchial lobes; 12) Number of chaetigers with branchiae; 13) Number of starting chaetiger for simple hooded hooks; 14) Number of simple hooded hooks per parapodium; 15) Number of simple capillaries per parapodium

this analysis is an adaptation of traditional methodology which delimits species based on the presence of one or more differences between the diagnostic morphological characters.

From a practical viewpoint, it is necessary to emphasize that the decision of what is a polymorphic character as opposed to a fixed one is the most relevant, since only fixed characters are suitable to delimit species (Davis and Nixon, 1992). In this respect, the populations' profile for each of the 11 populations analysed, assessed from the information taken from all specimens in each sample (Table 1), indicated that attributes 1-8 and 13, associated with the presence of branchial lobes in the anterior region of the body (before chaetiger 32 ), with the first chaetiger on which hooded hooks are present and the maxillary apparatus characteristics, were identical in all individuals in the samples. Therefore, these attributes were assessed as fixed and considered as the characters (invariant) in the sample that determined the differences among species. Attributes 9 and 11-15, related to the number of chaetae and hooks and to branchial development (number of lobes and number of chaetigers where they are present), were considered polymorphic (scored as "+-"“). Those attributes are not crucial for delimiting species unless polymorphisms overlap.

Our results agree with the observations previously made by Hilbig (1995) i.e. that the emphasis in lumbrinerid systematics has shifted from the often rather ill-defined differences in external morphology to more reliable, although less readily accessible characters of the jaws. In particular, Ninoe is a welldefined taxon, based upon a set of autapomorphies, one of them being the denticles of maxilla IV or maxillae III and IV (Orensanz, 1990).
A comparison of population profiles showed that in populations A-J, attributes 1-3, 5, 8 and 13 did not vary among samples. However, in population $J$, in characters 4, 6 and 7 (color of aciculae, number of teeth in maxillae II and III) differences were observed with populations A-I. Therefore, two species can be recognized: one characterized by the presence of four teeth in maxilla II and two teeth in maxilla III (population $\mathrm{K}=$ Ninoe marthae $\mathrm{n}$. sp.) and another (populations A-I = Ninoe jessicae n. sp.) defined by the presence of six teeth in maxilla II and one tooth in maxilla III (Table 1).

The Population Aggregation Analysis (PAA) also showed that in population $\mathrm{K}$, the fixed attributes for alternative states 1-3 and 6-8 (branchiae appearing after chaetiger 32, maxillae II and III with smooth margins, maxilla II with three teeth and maxillae III and IV with no teeth) and attribute 11 (fixed for alternative polymorphism) are completely different from those present in populations A-J due to the presence of only one branchial lobe. These differences in the population profile result from the inclusion in this population of a species of a different genus (Cenogenus eliae $\mathrm{n}$. sp.) from those in the previous populations.

The population profiles assessed from the 11 samples analysed, enable us to separate and validate the presence of the three species diagnosed in this study.

\section{ACKNOWLEDGMENTS}

Thanks are due to Erika Bistraín Meza and Laura González Ortiz for the previous identification of part of the biological material used for this study and to Jorge Malpica y Martínez for his help with the illustrations and figures. 


\section{REFERENCES}

Arias-González, J.E. - 1984. Diversidad, distribución y abundancia de anélidos (Poliquetos) en la Bahía de Mazatlán, Sinaloa, durante un ciclo anual. Tesis Profesional, Facultad de Ciencias, UNAM, México.

Carrera-Parra, L.F. - 2001. Recognition of Cenogenus Chamberlin, 1919 (Polychaeta: Lumbrineridae) based on type material. Proc. Biol. Soc. Wash., 114(3): 720-724.

Chamberlin, R.V. - 1919. The Annelida Polychaeta. Mem. Mus. Comp. Zool., 48: 1-514.

Davis, J.I. and K.C. Nixon. - 1992. Populations, genetic variation, and the delimitation of phylogenetic species. Syst. Biol., 41: 421-435.

De Queiroz, K. - 1998. The general lineage concept of species, species criteria, and the process of speciation. In: D.J. Howard and S.H. Berlocher (eds.), Endless forms: Species and speciation, pp. 57-75. Oxford University Press, Oxford.

Fauchald, K. - 1970. Polychaetous annelids of the families Eunicidae, Lumbrineridae, Iphitimidae, Arabellidae, Lysaretidae and Dorvilleidae from western Mexico. Allan Hancock Monogr. Mar. Biol., 5: 1-135.

Fauchald, K. - 1972. Benthic polychaetous annelids from deep water off Western Mexico and adjacent areas in the eastern Pacific Ocean. Allan Hancock Monogr. Mar. Biol., 7: 1-575.

Frame, A.B. - 1992. The lumbrinerids (Annelida: Polychaeta) collected in two northwestern Atlantic surveys with descriptions of a new genus and two new species. Proc. Biol. Soc. Wash., 105(2): 185-218.

González-Ortiz, L. - 1994. Los poliquetos (Annelida: Polychaeta) de la plataforma continental del Golfo de Tehuantepec, México. Tesis Profesional, Facultad de Ciencias, UNAM. México.

Hernández-Alcántara, P. - 1992. Los poliquetos (Annelida: Polychaeta) de la plataforma continental del Golfo de California, México. Taxonomía, abundancia numérica y distribución geográfica. Tesis Maestría. UACPyP-CCH, ICMyL, UNAM, México.

Hilbig, B. - 1995. 11. Family Lumbrineridae Malmgren, 1867, emended Orensanz, 1990. In: J.A. Blake, B. Hilbig and P.H. Scott (eds.), Taxonomic atlas of the benthic fauna of the Santa Maria Basin and the Western Santa Barbara Channel. Volume 5. The Annelida Part 2 polychaeta: Phyllodocida (Syllidae and scale-bearing Families), Amphinomida, and Eunicida, pp. 279313. Santa Barbara Museum of Natural History, California.

Jackson, M.L. - 1958. Soil chemical analysis. Prentice-Hall, New Jersey.

Kinberg, J.G.H. - 1865. Annulata nova. Ofv. Vet. Akad. Stockholm, Förh., 21: 559-574

Levenstein, R.Y. - 1977. A new genus and species of Polychaeta (Family Lumbrineridae) from the deep-water trenches of the North Pacific. In: D.J. Reish and K. Fauchald (eds.), Essays on the Polychaetous Annelids in Memory of Dr. Olga Hartman, pp. 189-198. Allan Hancock Foundation, Los Angeles, California.
Lezcano-Bustamante, B.E. - 1989. Estudio prospectivo de la distribución y abundancia de las poblaciones de anélidos poliquetos en la porción sur del Golfo de California. Tesis Profesional, Facultad de Ciencias, UNAM, México.

López-Hernández, M.I.P. - 1986. Anélidos poliquetos de las costas de Salina Cruz, Oaxaca. Tesis Profesional, Escuela Nacional de Ciencias Biológicas, IPN, México.

Orensanz, J.M. - 1973. Los anélidos poliquetos de la Provincia Biogeográfica Argentina IV., Lumbrineridae. Physis Secc. A, 32(85): 343-393.

Orensanz, J.M. - 1990. The eunicemorph polychaete annelids from Antarctic and Subantarctic seas with addenda to the Eunicemorpha of Argentina, Chile, New Zealand, Australia, and the Southern Indian Ocean. Biol. Antarctic Seas 21, Antarctic Res. Ser. 52: 1-183.

Oug, E. - 2002. Lumbrineridae from the Andaman Sea, Thailand, with notes on Oenonidae and Dorvilleidae (Annelida: Polychaeta). Phuket Mar. Biol. Cent. Sp. Publ., 24: 117-138.

Padilla-Galicia, E. and V. Solís-Weiss. - 1992. Distribución y nuevos registros de anélidos poliquetos en la plataforma continental del Estado de Sinaloa, costa Pacífica de México. In: P. Darwi and A.L. Welden (eds.), Biogeography of Mesoamérica, pp. 249-263. Tulane Studies in Zoology and Botany, Supp. Pub. 1.

Rioja, E. - 1941. Estudios Anelidológicos III. Datos para el conocimiento de la fauna de poliquetos de las costas mexicanas del Pacífico. An. Inst. Biol., Univ. Nal. Autón. México, 12: 669-746.

Salazar-Vallejo, S.I. - 1981. La colección de poliquetos (Annelida: Polychaeta) de la Facultad de Ciencias Biológicas de la Universidad Autónoma de Nuevo León, México. Tesis Profesional, Facultad de Ciencias Biológicas, UANL, México. $156 \mathrm{pp}$.

Sarti-Martínez, L.A. and V. Solís-Weiss. - 1987. Estudio prospectivo de la distribución, abundancia y diversidad de los anélidos poliquetos de la zona norte del Golfo de California In: Memorias V Simposium de Biólogía Marina, pp. 53-70. Universidad Autónoma de Baja California, México.

Strickland, J.D.H. and T.R. Parsons. - 1977. A practical handbook of seawater analysis. Fisheries Research Board of Canada, Bulletin 167, Canada.

Uebelacker, J.M. - 1984. Chapter 41, Family Lumbrineridae Malmgren, 1867. In: J.M. Uebelacker and P.G. Johnson (eds.), Taxonomic guide to the polychaetes of the Northern Gulf of Mexico. Final report to the Minerals Management Service, contract 14-12-001-29091, pp. 41.1-41.45. Barry A. Vittor and Associates, Inc., Mobile, Alabama.

Varela-Hernández, J.J. - 1993. Anélidos poliquetos de la plataforma continental del Jalisco, México. Tesis Profesional, Fac. Ciencias Biológicas, UdeG, México.

Walkley, A. and I.A. Black. - 1934. An examination of the Degthareff method for determining soil organic matter and a proposed modification of the chromic acid titration method. Soil Sci., 27: 29-38.

Received September 15, 2004. Accepted May 11, 2005. 